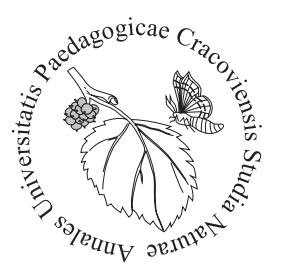

Annales Universitatis Paedagogicae Cracoviensis

Studia Naturae, 2: 114-123, ISSN 2543-8832

DOI: $10.24917 / 25438832.2 .9$

Zofia Konarzewska, Sylwia Śliwińska-Wilczewska ${ }^{\star}$, Adam Latała

Institute of Oceanography, University of Gdańsk, Gdynia, Poland, *ocessl@edu.pl

\title{
Allelopathic effect of the Baltic picocyanobacterium Synechococcus sp. on selected diatoms
}

\section{Introduction}

The allelopathy phenomenon was originally defined as a harmful effect between plants. This definition was used for the first time by Professor Hans Molisch (1937). As the result of the development of science and a better understanding of this phenomenon, the definition of allelopathy has evolved. The International Allelopathy Society (IAS, 1996) established the definition of allelopathy as the process in which the compounds secreted by different organism (vascular plant, algae, bacteria and fungi) influenced the growth and development of the both plant and animal organisms (Legrand et al., 2003). These chemical substances were called allelopathic compounds or allelochemicals (Leflaive, Ten-Hage, 2007), and organisms used them to protection against predators, and avoid competitors (Granéli et al., 2008).

In aquatic ecosystems, allelopathic interactions are still not very well recognised, because the distance between organisms which are able to secreting secondary metabolites is crucial to observe the allelopathic effect (Wolfe, 2000). Allelopathy in freshwater, brackish, and marine ecosystems depends on the production and secretion of active allelopathic compounds and their effective spread to other organisms (Lewis, 1986). Therefore, to demonstrate allelopathy between photoautotrophs, scientists need to perform a number of laboratory experiments.

It has been proven that several groups of phytoplankton, such as cyanobacteria, dinoflagellates, prymnesiophytes, green algae, and diatoms product allelopathic compounds (Subba Rao, Smith, 1995; Chiang et al., 2004; Żak, Kosakowska, 2015). Moreover, published data indicated that allelopathic effects have the competitive advantage of some phytoplankton species by eliminating physiologically more sensitive species (Sarkar et al., 2006). Moreover, the structure of phytoplankton (Legrand et al., 2003) and the formation of cyanobacterial and algal blooms may be determined by allelopathic 
interactions (Smayda, 1997; Weissbach et al., 2010). Massive and harmful cyanobacterial and algal blooms are a serious problem affecting not only the ecology but also the economy of the aquatic ecosystem (Anderson, 1989; Anderson et al., 2002). Massive blooms are formed by cyanobacteria (also picocyanobacteria from the genus Synechococcus), green algae, dinoflagellates, and diatoms (Beardall, 2008; Błaszczyk et al., 2010).

Little is known about the influence of cyanobacteria on diatoms (Sivonen, Jones 1999), and the specific mechanism of action of the allelopathic interactions is unexamined. It is impossible to demonstrate allelopathy in natural conditions, which is why it is important to contribute controlled experiments in laboratory environment. Therefore, in this study, we investigated the allelopathic effect of picocyanobacterium Synechococcus sp. on diatoms Nitzschia fonticola (Grunow) Grunow, Fistulifera saprophila (Lange-Bertalot \& Bonik) Lange-Bertalot, Navicula perminuta Grunow and Amphora coffeaeformis (C.Agardh) Kützing. In this study, the influence of picocyanobacteria was examined by adding the cell-free filtrate of Synechococcus sp. to studied diatoms. The results of this experiment may provide further information about allelopathic interactions between cyanobacteria and diatoms, which could be important to the understanding of cyanobacterial and algal blooms in aquatic ecosystems, including the Baltic Sea.

Material and methods

The experiments were conducted on the strain of picocyanobacterium Synechococcus sp. (BA-124) and four diatoms: Nitzschia fonticola (BA-34), Fistulifera saprophila (BA56), Navicula perminuta (BA-30), and Amphora coffeaeformis (BA-16) (Fig. 1). These species are typical representatives of Baltic diatoms; therefore, they were selected for the allelopathic experiment. The strains were isolated from the coastal zone of the Gulf of Gdańsk (southern Baltic Sea) and are maintained as uni-algal cultures in the Culture Collection of Baltic Algae (CCBA) at the Institute of Oceanography, University of Gdańsk, Poland (Latała et al., 2006). The tests on the 'batch cultures' were carried out in $25 \mathrm{~mL}$ glass Erlenmeyer flasks containing sterilised f/2 medium (Guillard, 1975). The media were prepared from Baltic water, which was filtered through Whatman $\mathrm{GF} / \mathrm{C}$ glass fibre filters, and autoclaved. Analysed organisms were grown 7 days in constant conditions of $18^{\circ} \mathrm{C}$ and $8 \mathrm{psu}$, under a $16: 8 \mathrm{~h}$ light : dark cycle at $10 \mu \mathrm{mol}$ photons $\mathrm{m}^{-2} \mathrm{~s}^{-1}$ and this were the control treatment conditions. Fluorescent lamps (Cool White 40W, Sylvania, USA) were used as source of irradiance. The intensity of PAR was measured using a LI-COR quantum-meter with a cosine collector. The donor and target organisms were acclimated to these culture conditions for 7 days; afterwards, actively growing cultures were used for the establishment of the allelopathic experiment.

Allelopathic interactions in monocultures were determined by using the modified method proposed by Suikkanen et al. (2004). Allelopathic interaction 



Fig. 1. Diatoms strains used in this study: Nitzschia fonticola (A), Fistulifera saprophila (B), Navicula perminuta (C) and Amphora coffeaeformis (D); scale bars $=10 \mu \mathrm{m}$

was studied by adding the filtrate obtained from the picocyanobacterial culture of Synechococcus sp. BA-124 to tested diatoms. The culture of picocyanobacteria was filtered through $0.45-\mu \mathrm{m}$ pore size Macherey-Nagel MN GF- 5 filters. The cellfree filtrate $(\mathrm{V}=10 \mathrm{~mL}$ ) was added to $25 \mathrm{~mL}$ Erlenmeyer flasks containing the tested diatoms $(\mathrm{V}=10 \mathrm{~mL})$. In all experiments, the ratio of picocyanobacterium to target species in Erlenmeyer flasks was adjusted to 1:1, based on the chlorophyll $a$ content (final chlorophyll $a$ concentration in the experimental cultures was $0.4 \mu \mathrm{g} \mathrm{chl} a \mathrm{~mL}^{-1}$ ). Control samples were prepared by adding mineral medium $f / 2$ with a volume equal to the added cell-free filtrate. Tests were conducted in triplicate, and all analysed species were obtained from early exponential growth phase.

The number of cells was counted using flow cytometer BD Accuri ${ }^{\text {im }}$ C6 Plus. Events are recorded in list mode. To avoid generating large files, samples can be run for $40 \mathrm{~s}$ at a delivery rate of $14 \mu \mathrm{l} \cdot \mathrm{min}^{-1}$, and the number of events is kept at less than 1000 per second. Events are recorded in standard filters: 670 LP (Detector FL3) and 675/25 (Detector FL4) (Marie et al., 2005). The number of cells in the experimental cultures was determined after the $1^{\text {st }}$ and $7^{\text {th }}$ day of the diatoms exposure to the picocyanobacterial filtrate. 


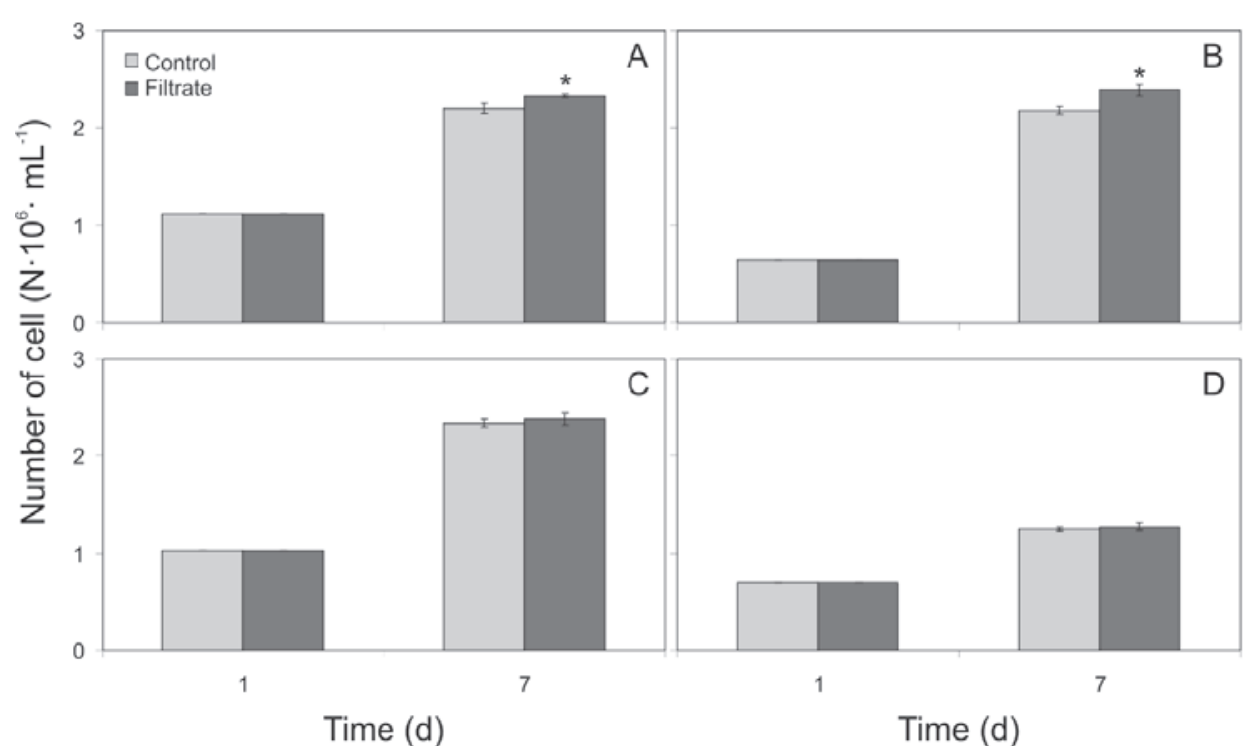

Fig. 2. The effect of the addition of cell-free filtrate from Synechococcus sp. BA-124 cultures on the growth of Nitzschia fonticola (A), Fistulifera saprophila (B), Navicula perminuta (C) and Amphora coffeaeformis (D) after the $1^{\text {st }}$ and $7^{\text {th }}$ days of exposition, expressed as a number of cells $(\mathrm{N})$. The values refer to means $(\mathrm{n}=3$, mean $\pm \mathrm{SD})$; asterisk indicates significant difference compared with control $(\mathrm{p}<0.05)$

Chlorophyll $a$ fluorescence was measured with a Pulse Amplitude Modulation (PAM) fluorometer (FMS1, Hansatech), using a $594 \mathrm{~nm}$ amber modulating beam with 4 step frequency control as a measuring light. Analysed species were taken for chlorophyll fluorescence analysis after the $7^{\text {th }}$ day of exposure to the filtrate. Before measurements, each sample taken from the culture was filtered through $13 \mathrm{~mm}$ glass fibre filters (Whatman GF/C). Before starting the experiment, the filter sample was adapted in the dark for about 10 minutes. The maximum quantum yield of PSII photochemistry $\left(\mathrm{F}_{\mathrm{v}} / \mathrm{F}_{\mathrm{m}}\right)$ and effective quantum yield of PSII photochemistry (ФPSII) was calculated (Campbell et al., 1998).

Analysis of variance (one-way ANOVA) was used to test for differences in analysed parameters between the target cultures treated with picocyanobacterial cellfree filtrates and the control over the experimental period. Data are reported as mean \pm standard deviation (SD). Levels of significance were ${ }^{\star} p<0.05$. The statistical analyses were performed using the Statistica ${ }^{\circledR} 13.1$ software.

\section{Results}

The effect of the cell-free filtrate addition obtained from Synechococcus sp. cultures on the growth of analysed diatoms Nitzschia fonticola, Fistulifera saprophila, Navicula perminuta and Amphora coffeaeformis after 1 and 7 days of exposition to the filtrates 


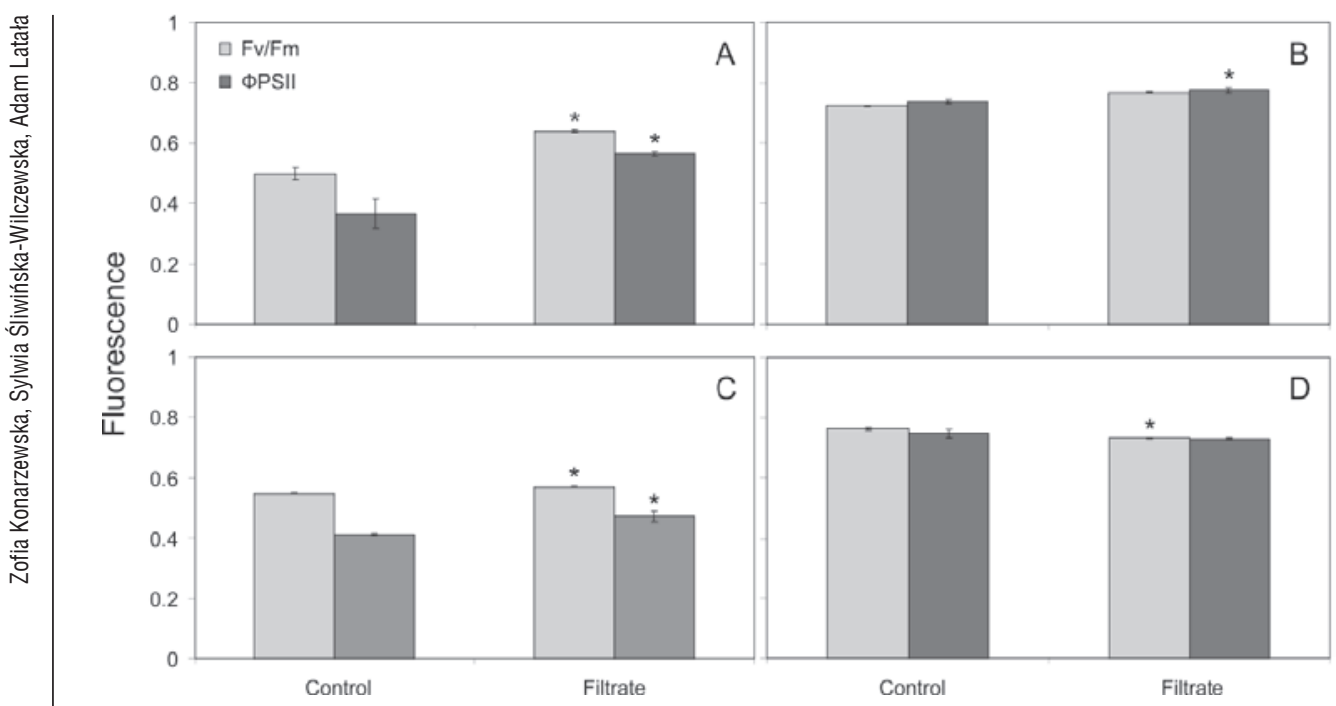

Fig. 3. The effect of the addition of cell-free filtrate from Synechococcus sp. BA-124 cultures on the fluorescence parameters $\mathrm{F}_{\mathrm{v}} / \mathrm{F}_{\mathrm{m}}$ and ФPSII of Nitzschia fonticola (A), Fistulifera saprophila (B), Navicula perminuta (C) and Amphora coffeaeformis (D) after the $7^{\text {th }}$ day of exposition; the values refer to means $(n=$ 3 , mean $\pm \mathrm{SD})$; asterisk indicates significant difference compared with control $(\mathrm{p}<0.05)$

are shown in figure 2. The results showed that addition of cell-free filtrate from Synechococcus sp. increased the number of cells of $N$. fonticola and F. saprophila compared to their control. After the $7^{\text {th }}$ day of the experiment for a filtrate addition, growth stimulation of $N$. fonticola and F. saprophila constituted $105 \%$ and $107 \%$, respectively (ANOVA, $\mathrm{p}<0.05$ ). In addition, it was observed that the cell-free filtrate obtained from picocyanobacterium did not affect the number of cells of N. perminuta and A. coffeaeformis (ANOVA, $\mathrm{p}>0.05$ ).

The effect of the addition of cell-free filtrate from Synechococcus sp. cultures on the fluorescence parameters $\mathrm{F}_{\mathrm{v}} / \mathrm{F}_{\mathrm{m}}$ and ФPSII of analysed diatoms after one week of exposition is showed in figure 3. The study indicated that the addition of cell-free filtrate obtained from Synechococcus sp. significantly affected the $\mathrm{F}_{v} / \mathrm{F}_{\mathrm{m}}$ and $\Phi$ PSII of $N$. fonticola and $N$. perminuta. After the $7^{\text {th }}$ day of exposition, it was noted that the addition of the filtrate resulted in increase of fluorescence parameters of analysed diatoms, which was higher by $29 \%$ and $4 \%$, respectively, for $\mathrm{F}_{\mathrm{v}} / \mathrm{F}_{\mathrm{m}}$ and $56 \%$ and $14 \%$, respectively for ФPSII, compared to a control (ANOVA, $\mathrm{p}<0.05$ ). Based on the results, it was found that the filtrate obtained from Synechococcus sp. also caused significant changes of the ФPSII value of $F$. saprophila. After one week of the experiment, the fluorescence parameter of this diatom was higher by $6 \%$, compared to control (ANOVA, $\mathrm{p}<0.05)$. On the other hand, it was noted that filtrate obtained from picocyanobacterium caused the inhibition of the $\mathrm{F}_{\mathrm{v}} / \mathrm{F}_{\mathrm{m}}$ parameter of $A$. coffeaeformis, which constituted 96\% (ANOVA, $\mathrm{p}<0.05)$. 
It is believed that cyanobacterial allelopathy may be one of the important factors affecting the formation of massive algal blooms in the aquatic ecosystems (e.g., Antunes et al., 2012; Rzymski et al., 2014). Picocyanobacteria plays an important role in aquatic ecosystems but not much is known about their allelopathic activity. Therefore, the main aim of this study was to investigate the allelopathic effect of picocyanobacterium Synechococcus sp. on growth and fluorescence parameters of Nitzschia fonticola, Fistulifera saprophila, Navicula perminuta, and Amphora coffeaeformis.

Allelopathic effects of the growth of the target organism by the production allelopathic compounds are the most frequently reported mode of the action of cyanobacteria and microalgae (Rzymski et al., 2014). In this study, we have also demonstrated that picocyanobacterium caused allelopathic effects against Baltic diatoms. The results showed that addition of cell-free filtrate from Synechococcus sp. increased the number of cells of N. fonticola and F. saprophila. In addition, it was observed that the cell-free filtrate obtained from picocyanobacterium did not affect the number of cells of $N$. perminuta and A. coffeaeformis. Only a few studies have documented the influence of the allelopathic effect of cyanobacteria on diatoms species. Information about the allelopathic interactions of Synechococcus sp. on Baltic diatom N. preminuta was described by Śliwińska-Wilczewska et al. (2016). In this study, the authors demonstrated that the addition of the cell-free filtrate obtained from the picocyanobacterium had an inhibitory effect on analysed diatom. Moreover, the study reveals that allelopathic activity was regulated by the intensity of light, temperature, and salinity. Keating (1977, 1978) also demonstrated the growth inhibition of selected diatom by the addition of filtrate obtained from a lake in which cyanobacteria was dominated. Similar results were reported by Lafforgue et al. (1995), who showed that the low biomass of Fragilaria crotonensis Kitton in Lake Aydat was the result of the allelochemicals obtained from Anabaena sp. More detailed data on the allelopathic effects of Baltic cyanobacteria on diatoms were provided by Suikkanen et al. (2004). In this study, the allelopathic effects of Baltic Nodularia spumigena Mertens ex Bornet \& Flahault, Anabaena lemmermannii P.G.Richter and Aphanizomenon flosaquae Ralfs ex Bornet \& Flahault on the diatom Thalassiosira weissflogii (Grunow) G.Fryxell \& Hasle were demonstrated. The authors showed that, after a single addition of the filtrate, all three analysed cyanobacteria had a generally negative effect on the tested diatom. Moreover, on the basis of the research, it was noted that the diatom of T. weissflogii showed some tolerance for a single addition of the filtrate, but its growth after repeated additions of the filtrate was significantly inhibited. Different characteristics, such as membrane permeability, may contribute to the sensitivity of some phytoplankton species to allelopathic compounds (Suikkanen et al., 2004). The sensitivity of organisms may also depend on the nature of 
allelopathic compounds to which they are exposed, because the same target organisms may react differently to the filtrate derived from different donor organisms.

There are also only a few reports on the growth stimulation of target organisms caused by allelochemicals produced by cyanobacteria. Suikkanen et al. (2005) showed that some Baltic cyanobacteria may stimulate natural plankton communities. The authors found that the addition of $N$. spumigena filtrate significantly increased the numbers of cells of N. spumigena and Anabaena sp. In our study, allelochemicals produced by Synechococcus sp. had the stimulatory effects on the growth of diatoms N. fonticola and F. saprophila. This indicated that the picocyanobacteria released some compounds that accelerated the growth of selected and co-existing diatoms.

Another possible effect of allelopathic compounds is their effect on the photosynthetic activity of target organisms. Measurements of chlorophyll $a$ fluorescence are non-invasive methods. Moreover, fluorescence measurements are a useful tool in the study of the allelopathy and ecophysiology of cyanobacteria and microalgae (Prince et al., 2008). In this study, it was found that the addition of filtrate stimulated and inhibited the fluorescence parameters $\mathrm{F}_{\mathrm{v}} / \mathrm{F}_{\mathrm{m}}$ and ФPSII of analysed diatoms. Published data indicated that the allelopathic compounds produced and released by some cyanobacteria can affect the photosynthesis, and detailed studies have shown that they act mainly on the photosystem II (PSII). Issa (1999) presented the inhibitory effect of the donor Oscillatoria sp. and Calothrix sp. on photosynthesis of Chlorella fusca Shihira \& R.W.Krauss. More detailed studies were conducted Prince et al. (2008). The authors analysed the impact of Karenia brevis (C.C.Davis) Gert Hansen \& Ø.Moestrup on fluorescence parameter $\mathrm{F}_{\mathrm{v}} / \mathrm{F}_{\mathrm{m}}$ of target diatoms Amphora sp., Asterionellopsis glacialis (Castracane) Round and Skeletonema costatum (Greville) Cleve. Inhibition of photosynthetic yield by extract obtained from $\mathrm{K}$. brevis coincided with a negative effect on the growth of target organisms. The effect of allelopathic compounds may be due to the different sensitivity of the target species (Mulderij et al., 2003), and this may explained the dominance of some species over other photoautotrophs.

It is believed that selective stimulation or inhibition of the target organism may affect the succession of selected cyanobacteria and microalgae in aquatic ecosystem (Legrand et al., 2003). The present research demonstrated the allelopathic effect of Synechococcus sp. either inhibited or stimulated the growth and fluorescence parameters of selected Baltic diatoms. To evaluate the significance of the picocyanobacterial allelopathy, more detailed studies are needed. These results showed that Synechococcus sp. allelopathy should be considered when estimating the potential interactions between picocyanobacteria and diatoms in aquatic ecosystems. quality of the paper. This study was supported by BMN grants, Poland, no. 538-G245-B568-17. 


\section{References}

Anderson, D.M. (1989). Toxic algal blooms and red tides: a global perspective. In: Okaichi, D.M. Anderson, T. Nemoto (eds.), Red Tides: Biology, Environmental Science and Toxicology. Elsevier. p. 11-16.

Anderson, D.M., Glibert, P.M., Burkholder, J.M. (2002). Harmful algal blooms and eutrophication: nutrient sources, composition and consequences. Estuaries, 25, 704-726.

Antunes, J.T., Leão, P.N., Vasconcelos, V.M. (2012). Influence of biotic and abiotic factors on the allelopathic activity of the cyanobacterium Cylindrospermopsis raciborskii Strain LEGE 99043. Microbial Ecology, 64, 584-592.

Beardall, J. (2008). Blooms of Synechococcus: An analysis of the problem worldwide and possible causative factors in relation to nuisance blooms in the Gippsland Lakes. Monash University, 1-8.

Błaszczyk, A., Toruńska, A., Kobos, J., Browarczyk-Matusiak, G., Mazur-Marzec, H. (2010). Ekologia toksycznych sinic. Kosmos, 59, 173-198.

Campbell, D., Hurry, V., Clarke, A.K., Gustafsson, P., Öquist, G. (1998). Chlorophyll fluorescence analysis of cyanobacterial photosynthesis and acclimation. Microbiology and Molecular Biology Reviews, 62, $667-683$.

Chiang, I.Z., Huang, W.Y., Wu, J.T. (2004). Allelochemicals of Botryococcus braunii (Chlorophyceae). Journal of Phycology, 40, 474-480. DOI: 10.1111/j.1529-8817.2004.03096.x

Granéli, E., Salomon, P.S., Fistarol, G.O. (2008). The role of allelopathy for harmful algal bloom formation. In: V. Evangelista, L. Barsanti, A. Frassanito, V. Passarelli, P. Gualtieri (eds.), Algal Toxins: Nature, Occurrence, Effect and Detection. NATO Science for Peace and Security Series A: Chemistry and Biology, Netherlands: Springer, p. 159-178.

Guillard, R.R.L. (1975). Culture of phytoplankton for feeding marine invertebrates. In: W.L. Smith, M.H. Chanley (eds.), Culture of Marine Invertebrate Animals. New York, USA: Plenum Press, 26-60.

IAS, (1996). First world congress on allelopathy. A science for the future. http://www-ias.uca.es/ bylaws. htm\#CONSTI.

Issa, A.A. (1999). Antibiotic production by the cyanobacteria Oscillatoria angustissima and Calothrix parietina. Environmental Toxicology and Pharmacology, 8, 33-37. DOI: 10.1016/S1382-6689(99)00027-7

Keating, K.I. (1977). Allelopathic Influence on Blue-Green Bloom Sequence in a Eutrophic Lake. Science, 196, 885-887. DOI: 10.1126/science.196.4292.885

Keating, K.I. (1978). Blue-green algal inhibition of diatom growth: transition from mesotrophic to eutrophic community structure. Science, 199, 971-973. DOI: 10.1126/science.199.4332.971

Lafforgue, M., Szeligiewicz, W., Devaux, J., Poulin, M. (1995). Selective mechanisms controlling algal succession in Aydat Lake. Water Science and Technology, 32, 117-127. DOI: 10.1016/02731223(95)00688-5

Latała, A., Jodłowska, S., Pniewski, F. (2006). Culture Collection of Baltic Algae (CCBA) and characteristic of some strains by factorial experiment approach. Archiv für Hydrobiologie, 165, Algological Studies, 122, 137-154. DOI: 10.1127/1864-1318/2006/0122-0137

Legrand, C., Rengefors, K., Fistarol, G.O., Granéli, E. (2003). Allelopathy in phytoplankton - biochemical, ecological and evolutionary aspects. Phycologia, 42(4), 406-419. DOI: 10.2216/i0031-8884-42$4-406.1$

Leflaive, J., Ten-Hage, L. (2007). Algal and cyanobacterial secondary metabolites in freshwaters: a comparison of allelopathic compounds and toxins. Freshwater Biology, 52, 199-214. DOI: 10.1111/j.13652427.2006.01689.x

Lewis, W.M.Jr. (1986). Evolutionary interpretation of allelochemical interactions in phytoplankton algae. The American Naturalist, 127, 184-194. 
Marie, D., Simon, N., Vaulot, D. (2005). Phytoplankton cell counting by flow cytometry. Algal culturing techniques, 1, 253-267.

Molisch, H. (1937). Der einfluss einer pflanze auf die andere - Allelopathie. Jena: G. Fisher, Verlag, 106 p.

Mulderij, G., Van Donk, E., Roelofs, G.M. (2003). Differential sensitivity of green algae to allelopathic substances from Chara. Hydrobiologia, 491, 261-271.

Prince, E.K., Myers, T.L., Kubanek, J. (2008). Effects of harmful algal blooms on competitors: Allelopathic mechanisms of the red tide dinoflagellate Karenia brevis. Limnology and Oceanography, 53, 531-541. DOI: $10.4319 /$ lo.2008.53.2.0531

Rzymski, P., Poniedziałek, B., Kokociński, M., Jurczak, T., Lipski, D., Wiktorowicz, K. (2014). Interspecific allelopathy in cyanobacteria: Cylindrospermopsin and Cylindrospermopsis raciborskii effect on the growth and metabolism of Microcystis aeruginosa. Harmful Algae, 35, 1-8. DOI: 10.1016/j. hal.2014.03.002

Sarkar, R.R., Petrovskii, S.V., Biswas, M., Gupta, A., Chattopadhyay, J. (2006). An ecological study of a marine plankton community based on the field data collected from Bay of Bengal. Ecological Modelling, 193, 589-601. DOI: 10.1016/j.ecolmodel.2005.08.038

Sivonen, K., Jones, G. (1999). Cyanobacterial toxins. In: I. Chorus, J. Bartram (eds.), Toxic cyanobacteria in water. A guide to their public health consequences, monitoring and management. World Health Organization. London: E \& FN Spon, p. 41-111.

Smayda, T.J. (1997). Harmful algal blooms: their ecophysiology and general relevance to phytoplankton blooms in the sea. Limnology and Oceanography, 42, 1137-1153. DOI: 10.4319/lo.1997.42.5_ part_2.1137

Suikkanen, S., Fistarol, G.O., Granéli, E. (2004). Allelopathic effects of the Baltic cyanobacteria Nodularia spumigena, Aphanizomenon flos-aquae and Anabaena lemmermannii on algal monocultures. Journal of Experimental Marine Biology and Ecology, 308, 85-101. DOI: 10.1016/j.jembe.2004.02.012

Suikkanen, S., Fistarol, G.O., Granéli, E. (2005). Effects of cyanobacterial allelochemicals on a natural plankton community. Marine Ecology Progress Series, 287, 1-9.

Śliwińska-Wilczewska, S., Pniewski, F., Latała, A. (2016). Allelopathic activity of the picocyanobacterium Synechococcus sp. under varied light, temperature and salinity conditions. International Review of Hydrobiology, 101, 1-9. DOI: 10.1002/iroh.201501819

Subba Rao, D.V., Pan, Y., Smith, S.J. (1995). Allelopathy between Rhizosolenia alata (Brightwell) and the toxigenic Pseudo-nitzschia pungens f. multiseries (Hasle). In: P. Lassus, G. Arzul, E.E. Le Denn, P. Gentien, C. Marcaillou (eds.), Harmful marine algal blooms. Paris: Lavoiser Intercept Ltd, p. 681-686.

Weissbach, A., Tillmann, U., Legrand, C. (2010). Allelopathic potential of the dinoflagellate Alexandrium tamarense on marine microbial communities. Harmful Algae, 10, 9-18. DOI: 10.1016/j.hal.2010.05.007

Wolfe, G.V. (2000). The chemical defense ecology of marine unicellular plankton: Constraints, mechanisms, and impacts. Biological Bulletin, 198, 225-244.

Żak, A., Kosakowska, A. (2015). The influence of extracellular compounds produced by selected Baltic cyanobacteria, diatoms and dinoflagellates on growth of green algae Chlorella vulgaris. Estuarine, Coastal and Shelf Science, 167, 113-118. DOI: 10.1016/j.ecss.2015.07.038

Abstract

It is commonly believed that the structure of phytoplankton and the formation of cyanobacterial and algal blooms may be explained by allelopathic interactions. The main aim of this study was to investigate the allelopathic effect of picocyanobacterium Synechococcus sp. on the following growth and fluorescence parameters: the maximum quantum yield of PSII photochemistry $\left(\mathrm{F}_{\mathrm{v}} / \mathrm{F}_{\mathrm{m}}\right)$, and the effective quantum yield of PSII photochemistry (ФPSII) of selected diatoms - Nitzschia fonticola, Fistulifera saprophila, Navicula perminuta and Amphora coffeaeformis. In this study, it was demonstrated that picocyanobacterium caused allelopathic 
effects against Baltic diatoms. The results showed that the addition of cell-free filtrate from Synechococcus sp. increased the number of cells of $N$. fonticola and F. saprophila. Moreover, it was found that picocyanobacterium was stimulated fluorescence parameters of N. fonticola, F. saprophila, and N. perminuta. On the other hand, it was noted that filtrate obtained from picocyanobacterium caused the inhibition of $\mathrm{F}_{\mathrm{v}} / \mathrm{F}_{\mathrm{m}}$ parameter of A. coffeaeformis. The results of this experiment may provide further information about allelopathic interactions between Baltic picocyanobacteria and diatoms that are crucial to the understanding of algal blooms in aquatic ecosystems.

Key words: allelopathy, Baltic Sea, diatom, growth, fluorescence, picocyanobacteria

Received: [2017.07.22]

Accepted: [2017.10.27]

\section{Zjawisko oddziaływania allelopatycznego bałtyckiej pikoplanktonowej sinicy Synechococcus sp. na wybrane gatunki okrzemek}

Streszczenie

Powszechnie uważa się, że oddziaływanie allelopatyczne może mieć wpływ na strukturę fitoplanktonu oraz tworzenie masowych zakwitów sinic oraz mikroglonów. Głównym celem niniejszych badań było wykazanie oddziaływania allelopatycznego pikoplanktonowej sinicy Synechococcus sp. na wzrost oraz parametry fluorescencji, charakteryzujące maksymalną wydajność fotosystemu II $\left(\mathrm{F}_{\mathrm{v}} / \mathrm{F}_{\mathrm{m}}\right)$ oraz rzeczywistą wydajność fotosystemu II na świetle (ФPSII) wybranych gatunków okrzemek: Nitzschia fonticola, Fistulifera saprophila, Navicula perminuta i Amphora coffeaeformis. Zaobserwowano, że pikoplanktonowa sinica wykazywała allelopatyczne właściwości na badane bałtyckie okrzemki. Na podstawie uzyskanych danych zanotowano, że dodanie przesączu z sinicy Synechococcus sp. stymulowało wzrost N. fonticola i F. saprophila. Ponadto zaobserwowano znaczący wzrost parametrów fluorescencji u N. fonticola, F. saprophila i N. perminuta. W pracy równieżwykazano, że przesącz powodował obniżenie wartości parametru $\mathrm{F}_{\mathrm{v}} / \mathrm{F}_{\mathrm{m}} \mathrm{u}$ A. coffeaeformis. Wyniki uzyskane w niniejszej pracy dostarczają szerszych informacji odnoście oddziaływania allelopatycznego, występującego pomiędzy wybranymi gatunkami sinic i okrzemek, które w znaczący sposób mogą przyczynić się do zrozumienia pojawiających się w wielu ekosystemach wodnych masowych zakwitów sinic i mikroglonów.

Słowa kluczowe: allelopatia, Morze Bałtyckie, okrzemki, wzrost, fluorescencja, pikoplanktonowe sinice

\section{Information on the authors}

\section{Zofia Konarzewska}

The field of her interest is allelopathic interactions of picocyanobacterium Synechococcus sp. and Baltic diatoms in monocultures. In her studies, she uses flow cytometer and PAM fluorymetry to determine allelopathic interactions between picocyanobacteria and selected diatoms - Nitzschia fonticola, Fistulifera saprophila, Navicula perminuta and Amphora coffeaeformis.

\section{Sylwia Śliwińska-Wilczewska}

In her research, she is interested in the allelopathy of cyanobacteria and microalgae, and particularly picocyanobacteria Synechococcus sp. Allelopathy plays an important role in interspecific competition and contributes to cyanobacterial bloom maintenance. In her study, the influences of allelochemicals on the growth, chlorophyll fluorescence, and photosynthesis irradiance curves of different phytoplankton species were investigated. She is also investigating what influences environmental factors have on produced allelopathic compounds on algae and cyanobacteria.

\section{Adam Latała}

His subjects of research include wide experience in the ecophysiology and ecotoxicology of marine benthic and planktonic algae, the influence of the main environmental factors such as salinity, temperature, and light on the photosynthesis, photoacclimation, fluorescence, respiration, and growth of algae from natural communities and cultured under laboratory conditions, and the use of fluorescence techniques to study algal and cyanobacterial ecophysiology and ecotoxicology. 